\title{
Słowo od redakcji
}

Oddając w ręce Czytelników 4. numer „Rocznika Europeistycznego”, pragniemy podzielić się kilkoma refleksjami dotyczącymi zarówno naszego czasopisma, jak i obszaru badawczego, którym się zajmujemy.

Cykl wydawniczy, liczne zadania stawiane przed naszym zespołem przez nową ustawę o szkolnictwie wyższym oraz wiele innych rozmaitych wyzwań spowodowały, że niniejszy numer ukazuje się już po wyborach do Parlamentu Europejskiego, a jeszcze przed ukonstytuowaniem się nowej ekipy obejmującej czołowe stanowiska w Unii Europejskiej. Można uznać, że europejski demos w maju 2019 r. w większym stopniu niż uprzednio zechciał decydować o przyszłości kontynentu. Pierwszy raz od 1994 r. frekwencja w skali całej UE przekroczyła 50\%, a w Polsce wzrosła z niecałych $25 \%$ do $45,7 \%$.

Polityczne skutki tego ożywienia nie są jeszcze do końca transparentne. $\mathrm{Na}$ pewno przełamano duopol dwóch najsilniejszych dotychczas partii - Europejskiej Partii Ludowej i socjaldemokratów - znacząco wzrosło poparcie dla ugrupowań kontestujących obecny kształt prawno-instytucjonalny UE. Z jednej strony swoje poparcie zwiększyli przeciwnicy dalszej integracji, zwolennicy „Europy Narodów" i podkreślania własnych narodowych tożsamości, z drugiej zaś wzrosła rola liberałów, zwolenników wzmocnienia struktur europejskich czy też - co jest znaczącą nowością - zwolenników ogólnoeuropejskiej ochrony środowiska. W każdym razie większy pluralizm w Parlamencie Europejskim będzie przekładać się na mniejszą stabilność i przewidywalność prac tego gremium, konieczność „docierania się" koalicji i negocjowania przetargów różnych sił politycznych w rozmaitych istotnych kwestiach, ale być może stanie się remedium na deklarowany „deficyt demokracji” oraz niską świadomość Europejczyków, że Parlament Europejski reprezentuje ich interesy.

Zespół przygotowujący niniejszy numer „Rocznika Europeistycznego” obserwował bieżące wydarzenia polityki europejskiej, przyglądał się także kierunkom, 
jakie dla polskiej nauki i szkolnictwa wyższego wytycza przyjęta w 2018 r. i etapami wchodząca w życie nowa ustawa nazwana „Konstytucją dla Nauki”. Jej regulacje wpływają również na kształt naszego periodyku - jako pismo ukazujące się już od kilku lat chcemy znaleźć się na nowych listach rekomendowanych czasopism naukowych. Wprowadzamy nową pozycję - recenzje ukazujących się książek z zakresu europeistyki. W tym numerze zrecenzowana zostanie książka dr hab. Joanny Dyduch Europeizacja polskiej polityki zagranicznej w perspektywie realizmu strukturalnego.

W niniejszym numerze pragniemy także poruszyć aktualną kwestię brexitu operację tę w artykule Trzy logiki geopolityczne brexitu analizuje prof. Tomasz G. Grosse - a także perspektywy rozwoju polityki społecznej UE — w tekście Quo Vadis Europe? Some thoughts on the European Union social policy zajęła się nimi prof. Ludmiła Dziewięcka-Bokun. Rozmaite aspekty bezpieczeństwa europejskiego w wymiarze globalnym analizuje dr Raul Kosta w artykule Rola NATO $w$ regulacji światowego porządku. Wyzwania i zagrożenia bezpieczeństwa $w X X I w$., w wymiarze wewnątrzeuropejskim dr Maciej Cesarz w materiale Kontrola mobilności a suwerenność terytorialna państw, natomiast polski wymiar bezpieczeństwa wojskowego przedstawia mgr Malwina Wach w tekście Etyka zawodowa żotnierzy Wojska Polskiego. Oprócz tego jeden z mniej znanych w Polsce, ale popularnych w UE mechanizmów finansowania aktywności społecznej prezentuje mgr Michał Biela w opracowaniu Teoretyczne założenia crowdfundingu oraz jego regulacje prawne w Unii Europejskiej $i w$ Polsce, z kolei stricte polską politykę samorządową w realiach Unii Europejskiej bada dr hab. Katarzyna Dojwa w artukule ,, Wygrani” $i$,,przegrani”. Analiza zmian poparcia uzyskanego przez radnych sejmików wojewódzkich kandydujących do parlamentu.

Życzymy miłej lektury!

Pawet Turczyński

Redaktor Naczelny

Rafat Juchnowski

Sekretarz Redakcji 